\title{
How Popular Culture Travels, Sylvie Mikowski, Yann Philippe (eds.)
}

\section{Frank Healy}

\section{(2) OpenEdition}

1 Journals

\section{Édition électronique}

URL : https://journals.openedition.org/etudesirlandaises/10437

DOI : 10.4000/etudesirlandaises. 10437

ISSN : 2259-8863

\section{Éditeur}

Presses universitaires de Caen

\section{Édition imprimée}

Date de publication : 31 décembre 2020

Pagination : 215-217

ISBN : 978-2-84133-996-9

ISSN : 0183-973X

\section{Référence électronique}

Frank Healy, "How Popular Culture Travels, Sylvie Mikowski, Yann Philippe (eds.) », Études irlandaises [En ligne], 45-2 | 2020, mis en ligne le 31 décembre 2020, consulté le 14 novembre 2022. URL : http:// journals.openedition.org/etudesirlandaises/10437; DOI : https://doi.org/10.4000/etudesirlandaises. 10437

\section{(c) (†)(2)}

Creative Commons - Attribution - Pas d'Utilisation Commerciale - Partage dans les Mêmes Conditions 4.0 International - CC BY-NC-SA 4.0

https://creativecommons.org/licenses/by-nc-sa/4.0/ 
academic religious studies and shows the way in tone and approach for future research into what Barr has convincingly described as the first and "only truly global institution the world has ever known" (p. 1).

Alexandra SLABY

\section{How Popular Culture Travels, Sylvie Mikowski, Yann Philippe (eds.), Reims, ÉPURE, 2019, 237 p.}

In the Introduction to their thought-provoking and thoroughly enjoyable volume How Popular Culture Travels, Mikowski and Philippe invite us on an archaeological dig through the multiple strata of complex cultural exchanges to uncover the bedrock of connections that form the essence of intercultural transfer - and, dare I say it, they have unearthed some gems... The starting point for the dig clearly illustrates the difficulty and the importance of reaching this bedrock: the origin of the song Drill Ye Tarriers, Drill is unclear, but given the highly pejorative connotation of the word tarrier to designate Irish and Scots Roman Catholics, it is difficult to imagine it being popular among Irish Americans before the New York Irish comic singer Thomas Casey published and popularised it in the 1880s as Drill Ye Terriers, Drill. Through John Ford's 1924 film The Iron Horse it then came to symbolically underline "the singular contribution [of Irish-Americans] [...] to the crucible of American culture" (p. 10), but the tangled roots of the song demonstrate the potential pitfalls in the study of how popular culture travels.

The book explores intercultural transfers between Ireland and the United States through wide-ranging contributions dealing with $19^{\text {th }}$ century music and art, to punk music and Internet memes. Each chapter examines how the "basic units of cultural transmission" travel between and within cultures. The "viral" nature of the dissemination of these basic units, or memes, a term first coined by the evolutionary biologist Richard Dawkins in the 1970s, corroborates the theory on the cultural transmission of art developed by Leo Tolstoy, and which is based on the "infectiousness" of cultural elements that pass from one individual to another (Leo Tolstoy, What is Art?, Indianapolis, Hackett Publishing Company, 1960).

To continue the viral metaphor, as the memes are disseminated they seem to depend, at least partly, on "super-spreaders", or what, in more cultural terms, would be known as an opinion-maker or a social media influencer if we're dealing with the Web. In Adèle Commins' chapter on the reception of Charles Villiers Stanford's music in $19^{\text {th }}$ century USA, music critics, including Richard Aldrich and Henry Krehbiel, promoted Stanford's music through their writings in newspapers such as The New York Times and The New York Tribune. Similarly, Amélie Dochy's chapter on the $19^{\text {th }}$ century Scottish painter Erskine Nicol demonstrates the importance of an international network of some British art dealers, in particular Arthur Tooth 
and Thomas McClean, who exhibited Nicol's work in their private galleries and in exhibitions that they organised for the purposes of selling his production to private owners. Diathí Kearney's chapter on the tour of the United States by National Irish Folk Theatre group Siamsa Tíre describes how a combined effort by politicians, promoters and, again, a crucial piece in The New York Times by the critic Clive Barnes, were instrumental in the success of the tour and provides further evidence of the central role of these "super-spreaders".

It was, of course, during the $19^{\text {th }}$ century that the rapid industrialisation and urbanisation of society allowed a massification of certain "products", including popular culture artefacts in music and art. The dissemination of memes accelerated during the $20^{\text {th }}$ century through the new mass media of radio and television, and reached the speed of light in the $21^{\text {st }}$ century with the advent of the Internet.

Tim Heron's chapter on Northern Irish punk rock exemplifies the importance of television, through programmes like Top of the Pops, and particularly radio, with "super-spreader" DJs like John Peel on Radio 1, in shaping the musical tastes of a generation of British youth. Heron's article also reminds us that cultural transmission is not a one-way street: punk rock, a music that has Irish folk songs as part of its DNA through country and western music, came back to form part of the colonisation by American culture of the Irish subconscious. Thus, as memes travel through a population they can "mutate", just like a virus, and therefore "infect" different populations in different ways and with different outcomes. These outcomes can be fairly benign or even positive, as was the case of Northern Irish punk rock music, which provided a cultural space for teenagers that crossed the religious divide. However, in other cases the results can be somewhat toxic.

This toxicity is illustrated by the two chapters on TV series. Flore Coulouma analyses Love/Hate, in which Dublin is portrayed as a mutated form of the US gangland. As she argues, it is a "specifically Irish [series] in its social, geographical and narrative setting, but it is also profoundly shaped by American references" and represents "one aspect of the global influence of American popular culture on the rest of the world" (p. 176). However, in Love / Hate Dublin forms the generic backdrop to a dystopian post-modern, post-industrial world of consumerism and violence.

Sylvie Mikowski's chapter on Ray Donovan reveals how the very idea of Irishness in the USA has been negatively affected by the recent sex scandals involving the Catholic Church. The positive images that were exemplified in 1930s and 1940s films starring Bing Crosby, Pat O’Brien and Mickey Rooney have alternated at different times with the "bad Paddy" stereotypes incarnated by Jimmy Cagney. In Ray Donovan, the positive memes conveying the image of the hard-working, devoted family man seem to be fighting a losing battle with the dark and negative memes associated with violence, alcoholism and sexual deviancy.

The last two chapters in the book examine the circulation of popular culture through the Internet. Anne Goarzin looks at the circulation of Internet memes and gifs involving leprechauns, cute cats and tasty treats, and how these tend to confirm ethnic, cultural and even gender stereotypes - or create new ones! A much darker aspect of the circulation of Internet memes is examined by Robert Johnson 
in the final chapter. Johnson shows that Irish servant migration to the Caribbean in the $17^{\text {th }}$ century, when transformed into an Irish slavery Internet meme, can become a "weaponized narrative" to obtain political advantage and claim cultural superiority over Afro-Americans.

This reminds us that popular culture has a political dimension, and that viral Internet memes can be vectors of influence, and therefore power. During this period of a global Covid-19 pandemic, it is worth considering how a real virus can also be a vector for cultural elements associated with national or racial cultural stereotypes... and conversely, how the virus may be helping to debunk some myths associated with national stereotypes.

How Popular Culture Travels is a highly stimulating and very enjoyable read, and it is to be hoped that it will encourage others to engage with this fascinating field of research.

Frank HeALY

\section{Jennifer Todd, Identity Change after Conflict: Ethnicity, Boundaries and Belonging in the Two Irelands, Basingstoke, Palgrave Macmillan, 2018, xvii +279 p.}

Ireland, North and South, has undergone significant social and political change in recent decades. Jennifer Todd seeks to understand the impact of these changes on collective identities and, specifically, how individuals have responded to these challenges. Todd, perhaps surprisingly, notes that her Northern respondents reported significantly higher levels of identity innovation than her Southern respondents (p. 3).

This provides the primary focus of the book: the attempt to understand how ordinary people manage identity change. Todd argues that the extent to which this is possible is often obscured by the assumption that "ethnicity" is especially resistant to change and that ethnic identities must be accommodated rather than transformed (p. 22). This has direct implications for how we view political institutions and informal norms demanding "recognition" for ethnic identities.

With admirable conceptual sophistication, Todd argues that such identities are usually complex composites: identity change cannot be reduced to a switch between simple identities. Rather, we should see identity change as a complex process of "reflexive distanciation" (p. 31) in which individuals both reinterpret and reposition themselves with respect to different aspects of their identities. One can remain a Protestant, for example, while opting to "do" Protestant differently (p. 31).

Todd's sharp eye for complexity is reflected in the inclusion of the story of "Ellie", brought up in a loyalist area, who moved away so that her children could grow up in a mixed environment and escape the influence of "bitterness". Despite 